\title{
FACTORS AFFECTING EARNING MANAGEMENT ON TRANSPORTATION CORPORATIONS IN INDONESIA
}

\author{
Yenni Arnas $^{1)}$, Suse Lamtiar ${ }^{2)}$, Zulina Kurniawati ${ }^{3)}$, Benny Kurnianto ${ }^{4)}$, Nawang Kalbuana ${ }^{5)}$ \\ Politeknik Penerbangan Indonesia Curug \\ E-mail: yenni.arnas@ppicurug.ac.id ${ }^{1}$, suse.lamtiar@ppicurug.ac.id ${ }^{2}$, zulina.kurniawati@ppicurug.ac.id ${ }^{3}$, \\ benny.kurnianto@ppicurug.ac.id ${ }^{4}$, nawang.kalbuana@ppicurug.ac.id $^{5}$
}

\begin{abstract}
The management of earnings or Earnings Management defined as management activities for adjusting earnings according to specific objectives. Therefore, empirical evidence showing the impact of Institutional and managerial Ownership, intellectual capital, audit quality on income management is necessary. 14 transportation companies listed on the Indonesian stock exchange were surveyed in accordance with the research criteria. A purposeful sampling method collected data. The SPSS 23 application tests the multiple linear regression hypothesis. Of the variables used in this study, only intellectual capital has a positive impact on profit management and can be used as one of the indicators in future research to measure income management actions.
\end{abstract}

Keywords : Earning Management, Institutional and managerial Ownership, Intellectua Capital, Audit Quality

\section{Introduction}

In 2019, there was an issue on manipulation of financial report at PT Garuda Indonesia Tbk. Dony O. and Chairal T., as commissioners of Garuda, made refusal in signing the Company's financial statement. They objected to claim revenues of USD 239.94 million. (Prastowo, 2019). Similar cases occurred at PT Bank Lippo Tbk. The management of PT Bank Lippo Tbk. reported assets of Rp22.8 trillion, a net loss of RP1.2 trillion and a CAR (capital adequacy ratio) of $4.2 \%$ (Khairani \& Wimelda, 2017).

These cases relate to the Financial Report. In such cases, the financial report is interpreted as a management output. In this output, the balance sheet and company performance in a particular period are included. It's for those who need economic decision-making (Widyaningrum, 2018). For full disclosure and transparency, the financial report should be presented to avoid misleading readers of a financial report (Antonia, 2008). The quality, application and actuality of the financial statements require a qualified auditor. In the auditing of financial reports and when there are mistakes or fraud, auditors who are integral always take care (Wiryadi \& Sebrina, 2013).

Adjusting the financial report for particular purposes is not uncommon for management. Management is most frequently used to manipulate the company's income this year or to stock earnings in the next year. The management of the earnings may lead to problems with the organization, since the shareholders and managers play a role. Management as an officer has more than the principal information. This information asymmetry makes it possible for the agent/management to manage earnings (Alfarano, 2005) (Lambert, 2012).

A good company must have corporate governance that can minimize the management of its income by separating owners and managers by distinguishing between management and managerial types of shareholding structures (Alfarano, 2005) (Lambert, 2012). Management is meant to reduce income management practices as much as possible. Other parties to the contract shall consider shareholders who are also managers of the company. The Board of Directors 
International Journal of Economics, Business, and Accounting Research (IJEBAR)

Peer Reviewed - International Journal

Vol-5, Issue-1, 2021 (IJEBAR)

E-ISSN: 2614-1280 P-ISSN 2622-4771

https://jurnal.stie-aas.ac.id/index.php/IJEBAR

should therefore be motivated to produce adequate financial statements. Furthermore, institutional ownership is expected to provide a similar monitoring mechanism (Yulistiani, 2020).

Intellectual capital is categorized into three categories, namely customers, structural capital and human capital (Yudhanti \& Shanti, 2011). Boekestein (2006) describes human capital as employee's knowledge, while structural capital is the entity's knowledge and customer capital is the client's own (Ulum, 2009). As the foundation of company growth is considered intellectual capital, the strategic role of intellectual capital grows and becomes even the main / major part to increase company value (Chen, 2004).

\section{Literarure Review}

\section{Stakeholder}

Stakeholders are a group/individual which influences/is influenced in achieving organizational objectives, quoted by Freeman and Reed (1983, page 91) as referred to by Kalbuana (2020). On this basis, management carries out activities and reports to stakeholders. Stakeholders can receive management information about their work, whether or not that information can be used, and stakeholders directly participate in or do not participate in the role of organisation. The theory of stakeholders aims to increase the value of organizational activities and reduce the loss of stakeholders as a result of a relationship between companies and stakeholders.

\section{Agency Theory}

This theory is based on managers' relationship as agents and investors as contract managers. As a consequence of the agreement between investor and agent, the manager can carry out activities that the investor does not prefer that allow for cost of agencies (Widyaningrum, 2018). These costs include monitoring costs (investor expenses so that managers are still in control of their behaviour), bonding (manager guaranteed costs will not harm investors) and residual losses These cost agencies include monitoring costs (decreasing percentage in welfare level after an agency relationship exist).

The conflict between this agency and the manager can lead to information asymmetry. Information asymmetry can be defined as a condition in which the information gathered between managers and investors differs and causes information imbalance. Managers and investors need intermediaries to control and monitor the performance of managers (agents) to match the needs of (principals) investors (Khairani \& Wimelda, 2017)

\section{Research Framework}

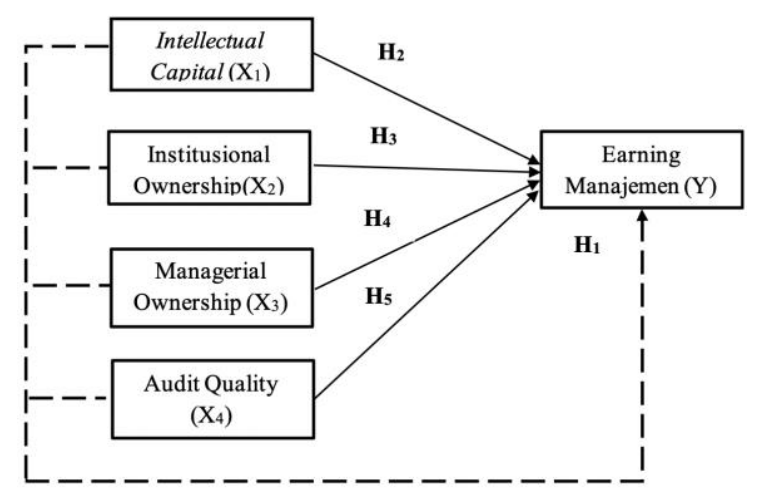

From this framework, the following hypotheses are formulated: 
International Journal of Economics, Business, and Accounting Research (IJEBAR)

Peer Reviewed - International Journal

Vol-5, Issue-1, 2021 (IJEBAR)

E-ISSN: 2614-1280 P-ISSN 2622-4771

https://jurnal.stie-aas.ac.id/index.php/IJEBAR

H1 : Intellectual capital, institutional and managerial ownership and audit quality simultaneously have an effecf toward earning management

$\mathrm{H} 2$ : Intellectual capital has an effecf toward earning management

H3 : Institutional ownership has an effecf toward earning management

H4 : Managerial ownership has an effecf toward earning management

H5 : Audit quality has an effecf toward earning management

\section{Methodology}

This study utilize financial statement of transport companies listed on IDX accessed at www.idx.co.id as secondary data.

\subsection{Measurement of Variables and Defining Operations}

\subsubsection{Intellectual Capital}

According to Sawarjuwono \& Kadir (2003), intellectual capital is defined as a combination of structural capital, customer capital, and human capital. This combination which has relationship to science and technology has a purpose to increase companies' value-added competitiveness in global. The intellectual capital variable is assessed using Pulic's VAIC TM coefficient developed by Ulum (2009) by calculating the following equation:

a. $\quad$ VA (Value Added)

Definition:

VA: Value Added

OUT: Output (total of sales and other revenue)

IN: Input (sales expenses and other costs other than employeement expenses)

b. VACA (Value Added Capital Employed)

VACA $=$ VA/CE

Definition:

VACA: Value Added Capital Employed

VA: Value Added

CE: Capital Employed (available funds; equity)

c. VAHU (Value Added Human Capital)

VAHU $=$ VA/HC

Definition:

VAHU: Value Added Human Capital

VA: Value Added

HC: Human Capital (employeement expense)

d. STVA (Structural Capital Value Added)

VAIC $^{\text {TM }}=$ VACA + VAHU + STVA

Definition:

STVA: Structural Capital Value Added

SC: Structural Capital (VA - HC)

VA: Value Added 
International Journal of Economics, Business, and Accounting Research (IJEBAR)

Peer Reviewed - International Journal

Vol-5, Issue-1, 2021 (IJEBAR)

E-ISSN: 2614-1280 P-ISSN 2622-4771

https://jurnal.stie-aas.ac.id/index.php/IJEBAR

e. $\quad$ VAICTM (Value Added Intellectual Coefficient of the three coefficients above)

VAIC $^{\text {TM }}=$ VACA + VAHU + STVA

\subsubsection{Institutional Ownership (INST)}

It is defined as ownership by an outside party to share ownership of a company. These shares can be owned by parties who can not easily rely on companies, such as the government, pension fund companies, banks, insurance and so on (Khairani \& Wimelda, 2017). INST compares the institutional ownership of shares with the total share capital of the company (Welvin, I. G., \& Herawati, A, 2010).

$$
\text { INST }=\frac{\text { Number of shares owned by an institutional party }}{\text { Total capital stock of the company in circulation }}
$$

\subsubsection{Managerial Ownership}

Managerial Ownership is defined as shares of ownership by the company management or by a subsidiary. Managerial ownership is calculated by comparing the shareholding by management with the total amount of share capital of the company (Welvin, I. G., \& Herawati, 2010).

$$
\text { MNJR }=\frac{\text { Number of shares owned by managers }}{\text { Total capital stock of the company in circulation }}
$$

\subsubsection{Audit Quality}

Quality of audit is measured by the four biggest public accounting firm as a dummy variable and is given a score of 1 on the financial statements audited by one of the biggest four of public accounting firms. The financial statements is given score 0 when audited by a public accounting firm other than the big four (Wiryadi \& Sebrina, 2013).

\subsubsection{Earning Management}

It is defined as management actions to adjust earning for specific objectives, either by reducing or increasing earning in financial reporting (Scott, 2011). Modified Jones Model approach is used to determine earnings management and identified by the score of discretionary accruals (Dechow et al, 1995). Discretionary accruals are gained by finding the following values:

a. Total Accrual (ToA)

$$
\mathrm{ToA}_{\mathrm{it}}=\mathrm{NInc}_{\mathrm{it}}-\mathrm{CFO}_{\mathrm{it}}
$$

Definition:

ToAit : Total Accrual company i year $\mathrm{t}$

NIncit. : Net Income (net earning before tax year $\mathrm{t}$ )

CFOit. : Cash Flow Operation (operating cash flow t)

b. Total Accrual (ToAit) with Ordinary Least Square (OLS) to obtain the value of the regression coefficient.

$$
\operatorname{ToA}_{\text {it }} / A_{\text {tit-1 }}=\beta_{1}\left(1 / A_{\text {tit-1 }}\right)+\beta_{2}\left(\Delta \operatorname{Rev}_{\text {tit }} / A_{\text {tit-1 }}\right)+\beta_{3}\left(P_{P E} E_{\text {it }} / A_{\text {tit-1 }}\right)+\varepsilon
$$

Definition:

ToAit: Total Accrual year tPPEit : Fixed assets year $\mathrm{t}$

Atit-1: Total assets of company $i$ in period $t-1 \beta 1,2,3$ : Coefisien 
International Journal of Economics, Business, and Accounting Research (IJEBAR)

Peer Reviewed - International Journal

Vol-5, Issue-1, 2021 (IJEBAR)

E-ISSN: 2614-1280 P-ISSN 2622-4771

https://jurnal.stie-aas.ac.id/index.php/IJEBAR

$\Delta$ Revtit: Year income $\mathrm{t}$ minus year income $\mathrm{t}-1 \varepsilon$ : Error

c. Nondiscretionary Accruals (NDAit)

$\operatorname{NDA}_{\text {tit }}=\beta_{1}\left(1 / A_{\text {tit-1 }}\right)+\beta_{2}\left(\left(\Delta \operatorname{Rev}_{\text {tit }}-\Delta \operatorname{Rec}_{\text {tit }} / A_{\text {tit-1 }}\right)+\beta_{3}\left(P_{P E} / A_{i t-1}\right)+\varepsilon\right.$

Definition:

NDAtit : Nondiscretionary Accruals company i year $\mathrm{t}$

PPEit: Fixed assets year $\mathrm{t}$

Atit-1: Total assets of company $i$ in period $t-1$

$\beta 1,2,3$ : Coefisien

$\Delta$ Revtit: Year income t minus year income t-1

$\varepsilon:$ Error

$\Delta$ Rectit : Trade accounts receivable for year $t$ less trade receivables for year $t-1$

d. Discretionary Accruals (DA).

$\mathbf{D A}_{\text {tit }}=\left(\mathbf{T A} \mathbf{A}_{\text {tit }} / \mathbf{A}_{\text {tit-1 }}\right)-\mathbf{N D A}_{\text {tit }}$

Definition:

DAtit: Discretionary Accruals company i year $\mathrm{t}$

TAtit: Total Accrual company i year $\mathrm{t}$

Atit-1: Total assets of company $i$ in period $t-1$

NDAtit : Nondiscretionary Accruals company i year $\mathrm{t}$

\subsection{Method of Data Analysis}

Multiple linear regression analysis was used to test Hypothesis in this examination. Autocorrelation test, a multicollinearity test, a heteroscedasticity test, and a normality test were completed to ensure the data is tested normally distributed and unbound from classical assumptions. Furthermore, the hypothesis test includes the coefficient of determination, $\mathrm{F}$ test (simultaneous), and $t$ test (partial test). The following equation describes the multiple linear regression analysis of the research.

$\mathrm{Y}=\alpha+\beta \mathrm{X}_{1}+\beta \mathrm{X}_{2}+\beta \mathrm{X}_{3}+\beta \mathrm{X}_{4}+\varepsilon$

Definition:

Y : Earning ManagementX2: Institutional Ownership

$\alpha \quad$ : ConstantaX3: Managerial ownership

$\beta \quad$ : Regression CoefficientX4: Audit Quality

$\mathrm{X} 1$ : Intellectual Capital $\varepsilon$ : Error

4. Analysis and Results

4.1 Statistical Description Analysis Results

The following table presents the statistical description analysis of the study. 
International Journal of Economics, Business, and Accounting Research (IJEBAR)

Peer Reviewed - International Journal

Vol-5, Issue-1, 2021 (IJEBAR)

E-ISSN: 2614-1280 P-ISSN 2622-4771

https://jurnal.stie-aas.ac.id/index.php/IJEBAR

Table 1.1 Variable Description

\begin{tabular}{|l|r|r|r|r|r|}
\hline & N & Minimum & Maximum & Mean & Std. Deviation \\
\hline Earning Management & 70 & .0000 & 2.4146 & .069571 & .2907837 \\
Intellectual Capital & 70 & .0000 & 27.3200 & 2.970083 & 4.5711032 \\
Institutional Ownership & 70 & .0000 & .8644 & .436889 & .2994370 \\
Managerial ownership & 70 & .0000 & .8646 & .284140 & .2978119 \\
Kualitas Audit & 70 & .0 & 1.0 & .171 & .3796 \\
Valid N (listwise) & 70 & & & & \\
\hline
\end{tabular}

Source: processed secondary data

On the basis of the information, from 2014 to 2018, 14 transport companies published 70 financial statements. The mean variable for earning management is 0.069571 and std. 0.2907837 deviation. The score minimum is 0.0000, and the maximum score is 0.0000. 2.22827.

An average of 2970083 and Std is the independent intellectual variable capital. 4.5711032 deviation. Coud is interpreted as having a VAICTM score of 2.00 to 2 in the company categorized as good performers. Intellectual capital has a small score in its independent variable. The max score of 0.0000 is 27.32 . The deviation score can be due to the company's diversity of treatment in the use of intellectual capital to increase the company's value.

The mean variable of institutional ownership was 0.436889 and std. 0.2994370 deviation. In other words $43.69 \%$ of the institution's average share. Min score is 0.0000 and max value of this variable. 0.9772 .

The mean score is 0.284140 and Std for management ownership variable. 0.2978119 deviation. This means that the sample is owned by parties associated with the company and its subsidiaries, which represents 28.41 percent of its average share. Min score of 0.0000 and max score 0.8646 of this variable.

The variable quality of audit is medium to 0.171 and std. 0.3796 deviation. deviation. This variable's maximum score is 1 and the minimum score is 0 . This value is the result of a stupid audit variable by the four largest and four non-largest public accountants.

\subsection{Result of Hypothesis Testing}

\subsubsection{Coefficient of Determination (Adjusted R2)}

Table 1.2 Determination Coefficient Test Results

\begin{tabular}{|c|r|r|r|r|r|}
\hline Model & R & R Square & Adjusted R Square & $\begin{array}{c}\text { Std. Error of the } \\
\text { Estimate }\end{array}$ & Durbin-Watson \\
\hline 1 & $.643^{\mathrm{a}}$ & .413 & .377 & .2294740 & 1.746 \\
\hline
\end{tabular}
a. Predictors: (Constant), Audit Quality, Intellectual Capital, Managerial Ownership, Institutional
Ownership
b. Dependent Variable: Quality Audit, Intellectual Capital, Managerial Ownership, Institutional
Ownership
Source: processed secondary data

Table 1.2 illustrate that coefficient of determination (Adjusted R2) score is 0.377. The variable intellectual capital, institutional ownership, managerial ownership, and audit quality have an effect of $37.7 \%$ on earning management. Other variables that affect earning management that were not covered in this study is $62.3 \%$. 
International Journal of Economics, Business, and Accounting Research (IJEBAR)

Peer Reviewed - International Journal

Vol-5, Issue-1, 2021 (IJEBAR)

E-ISSN: 2614-1280 P-ISSN 2622-4771

https://jurnal.stie-aas.ac.id/index.php/IJEBAR

\subsubsection{Statistical Test $\mathrm{F}$ (Simultaneous Test)}

Table 1.3 F Statistik test Result

\begin{tabular}{|c|c|c|c|c|c|c|}
\hline \multicolumn{7}{|c|}{ ANOVA } \\
\hline \multicolumn{2}{|c|}{ Model } & Sum of Squares & df & Mean Square & $\mathrm{F}$ & Sig. \\
\hline \multirow[t]{3}{*}{1} & Regression & 2.412 & 4 & \multirow{3}{*}{$\begin{array}{l}.603 \\
.053\end{array}$} & \multirow[t]{3}{*}{11.449} & \multirow[t]{3}{*}{.000} \\
\hline & Residual & 3.423 & 65 & & & \\
\hline & Total & 5.834 & 69 & & & \\
\hline \multicolumn{7}{|c|}{ a. Dependent Variable: Earning management } \\
\hline \multicolumn{7}{|c|}{$\begin{array}{l}\text { b. Predictors: (Constant), Audit Qualify, Intelloctual Capital, Managorial Ownership, Institutional } \\
\text { Ownership } \\
\text { Source: processed secosdary data }\end{array}$} \\
\hline \multicolumn{7}{|c|}{ Source: processed secondary data } \\
\hline
\end{tabular}

According to table 1.3, the score obtained from the F test were 11.444. This means that the $\mathrm{F}$ test score obtained is bigger than the $\mathrm{F}$ table score of 2.513. In conclusion, the variables of intellectual capital, audit quality, and institutional ownership as well as managerial ownership simultaneously have effect toward earning management. Therefore, H1 is accepted.

\subsubsection{Statistical Test $t$ (Partial Test)}

Table 1.4 "t $t$ " Statistik Test Result

\begin{tabular}{|c|c|c|c|c|c|}
\hline \multirow[b]{2}{*}{ Model } & \multicolumn{2}{|c|}{$\begin{array}{c}\text { Unstandardized } \\
\text { Coefficients }\end{array}$} & \multirow{2}{*}{$\begin{array}{c}\begin{array}{c}\text { Standardized } \\
\text { Coefficients }\end{array} \\
\text { Beta } \\
\end{array}$} & \multirow[b]{2}{*}{$t$} & \multirow[b]{2}{*}{ Sig. } \\
\hline & $\mathrm{B}$ & Std. Error & & & \\
\hline (Constant) & .034 & .138 & & .250 & .804 \\
\hline Intellectual Capital & .041 & .006 & .650 & 6.413 & .000 \\
\hline Institutional Ownership & .064 & .199 & .066 & -.321 & .749 \\
\hline Institutional Ownership & -.160 & .200 & -.163 & -.798 & .428 \\
\hline Kualitas Audit & .084 & .078 &. .109 & -1.079 & .284 \\
\hline
\end{tabular}

a. Dependent Variable: Eaming management

Source: processed secondary data

According to Table 1.4, the intellectual capital variable obtained t score 6.413 and coefficient score 0.041 . ' $t$ ' arithmetic is higher than score of $t$ table (1.66827). It indicates that the effect of intellectual capital variable toward earning management is positive. Therefore, $\mathrm{H} 2$ is accepted.

The second variable, institutional ownership, has a t score of -0.332 and a coefficient 0.064. The $t$ score is less than $t$ table obtained (1.66792). It shows that the effect of institutional ownership variable toward earning management is negative. Therefore, H3 is declined. The results of this research correspond to the research directed by Welvin, I. G., \& Herawati (2010), Widyaningrum (2018). The huge share ownership supposes making institutional has control over operational activities. In fact institutional ownership could not limit earning management practices (Widyaningrum, 2018).

The third variable, managerial ownership, has a t score -0.798 and a coefficient -0.160 . The $\mathrm{t}$ score is less than the t table score obtained. It shows that managerial ownership has no effect on earning management. Hence, $\mathrm{H} 4$ is rejected. The results of this study are corresponding to the research conducted by Welvin, I. G., \& Herawati (2010), Abed et al. (2012), and Widyaningrum, (2018). However, this research disputes the results of research conducted by Nabila (2013), Mahariana \& Ramantha (2014), and Sari \& Putri (2014) which conclude that negative effect 
International Journal of Economics, Business, and Accounting Research (IJEBAR)

Peer Reviewed - International Journal

Vol-5, Issue-1, 2021 (IJEBAR)

E-ISSN: 2614-1280 P-ISSN 2622-4771

https://jurnal.stie-aas.ac.id/index.php/IJEBAR

occurred from managerial ownership toward earning management. Corresponding to Sari \& Putri (2014), earning management can be reduced since there is managerial ownership through managers who can protect their shares dropping due to these actions.

Audit quality, as the last variable, has $t$ score -1.079 and coefficient score -0.084 . The $t$ table score was still higher than $t$ score. It indicates that there is no effect from audit quality toward earning management. Thus, H5 is rejected. This result is corresponding to the research conducted by Welvin, I. G., \& Herawati (2010) and Wiryadi \& Sebrina (2013). Companies audited by big KAP do not necceceraly mean they can restrain the occurrence of earning management (Wiryadi \& Sebrina, 2013).

\section{Result And Conclusions}

The study concludes with the effect of management of transportation companies in terms of intellectual capital or corporate governance simultaneously supported by institutional ownership, management and audit quality. The effect on earnings management was confirmed by the intellectual capital variable. Nevertheless, the effect of institutional ownership and management ownership on earnings management and audit quality has been denied. $\mathrm{H} 1$ and $\mathrm{H} 2$ are therefore accepted only. The result confirms the impact on earnings management of variable intellectual capital. It shows empirically that intellectual capital can be an indicator of income management.

According to the results, both institutional and managerial ownership measured/proxied management variable have no impact on income management. Corporate governance cannot limit earning management practices by using institutional ownership structure expected to have control over operating activities of the company. Accordingly, shareholding in the managing company does not preclude an adjustment of management of earnings.

The audit quality variable has no impact on earnings management, according to the results of this study. While the financial report has been audited by the big four KAP, the company's profit management behavior cannot be limited.

This research has several boundaries which further research could improve. The research constraints and recommendations for future research are: 14 transportation companies from a total of 70 companies in idx.co.id are investigated in this research. In the forthcoming research, similar business sectors like infrastructure and utilities should be used or supplemented. In this study, two variables based on the share ownership structure were taken up by corporate governance. In order to measure/support corporate governance, any forthcoming research is proposed to use the variables of the audit agency, Independent Commissioner and the board of directors. Rarely do research study the correlation between the impact on income management of intellectual capital. Most studies use intellectual capital variables for measuring enterprise performance as indicators. The treatment of intellectual capital as a variable that adds value to the company is influencing this condition.

\section{Reference:}

Astuti, R. N., Fachrurrozie, F., Amal, M. I., \& Zahra, S. F. (2020). Does Audit Committee Quality Mediate Determinants of Intellectual Capital Disclosure?. The Journal of Asian Finance, Economics, and Business, 7(7), 199-208.

Boekestein, B. (2006). "The relation between intellectual capital and intangible assets of pharmaceutical companies”. Journal of Intellectual Capital. Vol. 7 No. 2. pp. 241-253.

Chen, J., Zhu, Z., \& Xie, H. Y. (2004). Measuring intellectual capital: a new model and empirical study. Journal of Intellectual capital. 
International Journal of Economics, Business, and Accounting Research (IJEBAR)

Peer Reviewed - International Journal

Vol-5, Issue-1, 2021 (IJEBAR)

E-ISSN: 2614-1280 P-ISSN 2622-4771

https://jurnal.stie-aas.ac.id/index.php/IJEBAR

Desiyanti, E., Kalbuana, N., Fauziah, S., \& Sutadipraja, M. W. (2020). Eka Desiyanti. MALA'BI: Jurnal Manajemen Ekonomi STIE Yapman Majene, 3(1), 1-5.

Freeman, R.E., and Reed. (1983). "Stockholders and stakeholders: a new perspective on corporate governance". Californian Management Review. Vol 25. No. 2. pp. 88-106.

Jannah, M., Fahlevi, M., Paulina, J., Nugroho, B. S., Purwanto, A., Subarkah, M. A., ... \& Cahyono11, Y. (2020). Effect of ISO 9001, ISO 45001 and ISO 14000 toward Financial Performance of Indonesian Manufacturing. Systematic Reviews in Pharmacy, 11(10), 894902.

Kalbuana, N., Widagdo, R. A., \& Yanti, D. R. (2020). Pengaruh Capital Intensity, Ukuran Perusahaan, Dan Leverage Terhadap Tax Avoidance Pada Perusahaan Yang Terdaftar Di Jakarta Islamic Index. Jurnal Riset Akuntansi Politala, 3(2), 46-59.

Kalbuana, N., Solihin, S., Yohana, Y., \& Yanti, D. R. (2020). The Influence Of Capital Intensity, Firm Size, And Leverage On Tax Avoidance On Companies Registered In Jakarta Islamic Index (JII) Period 2015-2019. International Journal of Economics, Business and Accounting Research (IJEBAR), 4(03).

Kalbuana, N., Kurnianto, B., Saputro, R., Hendra, O., Utami, S., \& Widagdo, R. A. (2020). The Effect of Audit Quality, Managerial ownership, Institutional ownership, and Intellectual Capital toward Earning Management on Transportation Corporations in Indonesia. Solid State Technology, 63(5), 9176-9184.

Kalbuana, N., \& Yulistiani, N. (2020). Pengaruh Intellectual Capital, Tata Kelola Perusahaan Dan Kualitas Audit Terhadap Manajemen Laba. JABI (Jurnal Akuntansi Berkelanjutan Indonesia), 3(1), 56-71.

Kurnianto, B., Kalbuana, N., \& Rusiati, U. R. (2019). Pengaruh Good Corporate Governance, Profitabilitas, Leverage, dan Ukuran Perusahaan Terhadap Integritas Laporan Keuangan (Studi Empiris pada Perusahaan yang terdaftar di LQ45 Tahun 2014-2018).

Karajeh, A. I. S. (2019). Voluntary disclosure and earnings quality: evidence from ownership concentration environment. Management Research Review.

Lambert, R. A., Leuz, C., \& Verrecchia, R. E. (2012). Information asymmetry, information precision, and the cost of capital. Review of finance, 16(1), 1-29.

Lamtiar, S., Arnas, Y., Rusdiyanto, A. A., Kalbuana, N., Prasetyo, B., Kurnianto, B., ... \& Utami, S. Liquidity Effect, Profitability Leverage to Company Value: A Case Study Indonesia. European Journal of Molecular \& Clinical Medicine, 7(11), 2800-2822.

Purwanti, T., Kalbuana, N., \& Rahmawati, F. (2019). Pengaruh Good Corporate Governance, Audit Fee dan Kualitas Audit Terhadap Integritas Laporan Keuangan (Studi Empiris pada Perusahaan BUMN yang Terdaftar di BEI Tahun 2014-2018).

Sutadipraja, M. W., Kalbuana, N., Rahmawati, D., \& Desiyanti, E. (2020). Marista Winanti Sutadipraja. MALA'BI: Jurnal Manajemen Ekonomi STIE Yapman Majene, 3(1), 6-12.

Seralurin, Y. C., Larasati, R., \& Pattiasina, V. (2020). Institutional Ownership as Moderation of Execution Price Relationship and Employee Stock Ownership Program (ESOP). The International Journal of Social Sciences World (TIJOSSW), 2(2), 85-99.

Solikhah, B., Wahyudin, A., \& Rahmayanti, A. A. W. (2020). The Extent of Intellectual Capital Disclosure and Corporate Governance Mechanism to Increase Market Value. The Journal of Asian Finance, Economics and Business (JAFEB), 7(10), 119-128. 
International Journal of Economics, Business, and Accounting Research (IJEBAR)

Peer Reviewed - International Journal

Vol-5, Issue-1, 2021 (IJEBAR)

E-ISSN: 2614-1280 P-ISSN 2622-4771

https://jurnal.stie-aas.ac.id/index.php/IJEBAR

Sun, N., Salama, A., Hussainey, K., \& Habbash, M. (2010). Corporate environmental disclosure, corporate governance and earnings management. Managerial Auditing Journal.

Widyaningrum, R., Amboningtyas, D., \& Fathoni, A. (2018). The Effect Of Free Cash Flow, Profitability, And Leverage To Earnings Managemet With Good Corporate Governance As A Moderating Variable (Empirical Study on Banking Companies Listed on the Indonesian Stock Exchange For The Period 2012-2016). Journal of Management, 4(4).

Zureigat, Q. M. (2011). The effect of ownership structure on audit quality: Evidence from Jordan. International Journal of Business and Social Science, 2(10).

Yohana, Y., Kalbuana, N., Fadila, Z. N., \& Permatasari, D. (2018). Pengaruh Leverage dan Kualitas Audit Terhadap Volatilitas Saham (Studi Empiris pada Perusahaan Dagang yang terdaftar di Bursa Efek Indonesia). Seminar Nasional dan The 5th Call For Syariah Paper (SANCALL) 2018. 